ХОЛОНДОВИЧ І.І.

\title{
ПІДСТАВИ ОСКАРЖЕННЯ ПОВІДОМЛЕННЯ ПРО ПІДОЗРУ У КРИМІНАЛЬНОМУ ПРОВАДЖЕННІ
}

\begin{abstract}
Актуальність статті полягає в тому, що однією з найважливіших процесуальних дій у кримінальному провадженні на стадії досудового розслідування $\epsilon$ повідомлення особі про підозру у вчиненні кримінального правопорушення, з яким кримінальний процесуальний закон пов'язує початкову стадію притягнення такої особи до кримінальної відповідальності. Зважаючи на важливість зазначеної процесуальної дії, необхідним $є$ не лише суворе дотримання процесуального законодавства під час іiі проведення, але й розроблення однозначного та однакового розуміння учасниками кримінального провадження процедури іiї проведення, в чому наразі існують суперечності. 3'ясовано, що підозра сама собою $є$ мінімальним стандартом у контексті доказування. 3 погляду Європейського суду з прав людини, тут достатньо мінімальних ознак, які переконають стороннього спостерігача, що особа може бути причетна до вчинення кримінального правопорушення. При цьому таке поняття як «обгрунтованість підозри» для місцевих судів здебільшого визначається думкою прокурора під час обрання підозрюваному запобіжного заходу. Наголошено, що сформована судова практика з моменту внесення відповідних змін свідчить про небажання слідчих суддів проводити аналіз оголошеної підозри та перевіряти докази, якими вона обгрунтовується. При цьому вони посилаються на те, що докази досліджуються судом при розгляді справи по суті. Тим самим слідчі судді фактично не реалізують функцію судового контролю за дотриманням прав, свобод та інтересів осіб у кримінальному провадженні. Зроблено висновок, що повідомлення про підозру може бути оскаржено як процесуальна дія. Підставою для іiі оскарження, згідно $з$ п. 1 ч. 1 ст. 303 Кримінально-процесуального кодексу України, можуть слугувати порушення процесуальних норм. Варто зазначити, якщо досудове розслідування уже завершене, то повідомлення про підозру оскаржити не можна Незважаючи на те, що в нормі це прямо вказано, але захисники все одно подають відповідні клопотання до слідчого судді. Якщо суд першої інстанції задовольнить скаргу про скасування підозри, не врахувавши терміни, вона, вірогідно, буде скасована в апеляційній інстанції.
\end{abstract}

Ключові слова: кримінальне провадження, оскарження, повідомлення про підозру, прочесуальна дія, досудове розслідування.

The relevance of the article is that one of the most important procedural actions in criminal proceedings at the stage of pre-trial investigation is the notification to the person of suspicion of committing a criminal offense, with which the criminal procedural law links the initial stage of bringing such person to justice. Given the importance of the said procedural action, it is necessary not only to strictly adhere to the procedural law during its implementation, but also to develop a clear and uniform understanding of the procedure of its conduct by the participants in criminal proceedings, in which there are currently contradictions. It has been found that suspicion is itself a minimum standard in the context of proof. From the point of view of the European Court of Human Rights, there are enough minimal signs to convince a third-party observer that a person may be involved in a criminal offense. At the same time, the notion of suspicion is, for the local courts, largely determined by the opinion of the prosecutor when choosing a suspected measure of restraint. It is emphasized that the established case-law from the moment of making the corresponding changes indicates the unwillingness of the investigating judges to analyse the announced suspicion and to examine the evidence, which it substanti-

( ) ХОЛОНДОВИЧ І.І. - здобувач кафедри кримінально-правових дисциплін (Харківський національний університет внутрішніх справ) 
ates, referring to the fact that the evidence is examined by the court when considering the merits of the case. Thus, the investigating judges do not actually exercise the function of judicial control over the observance of the rights, freedoms and interests of persons in criminal proceedings. It is concluded that the notification of suspicion may be appealed as a procedural action, and the basis for its appeal, according to paragraph 1 of Part 1 of Art. 303 of the CPC of Ukraine, violations of procedural rules may serve. It should be noted that if the pre-trial investigation is already completed, then the suspicion report is not contested. Although it is explicitly stated in the norm, defence attorneys still apply to the investigating judge. If the trial court granted the suspicion dismissal without due time, it would most likely be overturned on appeal.

Key words: criminal proceeding, appeal, message about suspicion, legal proceeding, pre-judicial investigation.

Вступ. Однією з найважливіших процесуальних дій у кримінальному провадженні на стадії досудового розслідування є повідомлення особі про підозру у вчиненні кримінального правопорушення, з яким кримінальний процесуальний закон пов'язує початкову стадію притягнення такої особи до кримінальної відповідальності. Зважаючи на важливість зазначеної процесуальної дії, необхідним $є$ не лише суворе дотримання процесуального законодавства під час ії проведення, але й розроблення однозначного та однакового розуміння учасниками кримінального провадження процедури ії проведення, в чому наразі існують суперечності.

16 березня 2018 р. набули чинності зміни до Кримінального процесуального кодексу України, якими передбачено право оскаржувати повідомлення про підозру під час досудового розслідування. Після прийняття зазначених змін науковці вказали на високу ймовірність затягування досудового розслідування, чим зумовлено потенційне порушення прав людини і громадянина.

Крім цього, практичні працівники наголошують, що оскарження повідомлення про підозру - це шанс підозрюваного корупційним шляхом уникнути кримінальної відповідальності; інші фахівці стверджують, що, навпаки, в законі варто було б закріпити можливість негайного оскарження повідомлення про підозру, а не після спливу 1-2 місяців.

Попри неоднозначну позицію науковців щодо прийнятих змін, на нашу думку, оскарження повідомлення про підозру є важливим чинником ефективнішого забезпечення прав і свобод людини і громадянина під час досудового розслідування, а також спрямоване на уникнення професійних помилок слідчого чи прокурора.

Актуальність окреслених питань підтверджується значною кількістю публікацій науковців та практичних працівників. Зокрема, їх досліджували Ю.П. Аленін, О.В. Баганець, О.В. Капліна, В.Т. Маляренко, О.М. Овчаренко, М.А. Погорецький, О.Ю. Татаров, С.С. Терещук, Л.Д. Удалова, O.В. Фараон, В.І. Фаринник.

Постановка завдання. Метою статті є здійснення комплексного аналізу законодавчих підстав оскарження повідомлення про підозру та розробка пропозицій для вдосконалення кримінального процесуального законодавства України щодо цього питання.

Результати дослідження. Повідомлення особі про підозру має важливе значення, оскільки ця процесуальна дія $є$ одним із засобів забезпечення невідворотності відповідальності осіб, які вчинили кримінальне правопорушення. В подальшому обгрунтована підозра дозволяє суду призначити таким особам справедливе покарання відповідно до характеру й тяжкості вчиненого кримінального правопорушення. Після цього процесуальне становище підозрюваного погіршується, оскільки слідчий, прокурор набувають права застосовувати до неї заходи забезпечення кримінального провадження, передбаченим Розділом 2 Кримінально-процесуального кодексу (далі - КПК) України.

Юридичне значення повідомлення особі про підозру полягає також і в тому, що на стадії досудового розслідування настає певний етап, пов'язаний з тим, що у процесі розслідування зібрано достатньо доказів для підозри конкретної особи у вчиненні кримінального правопорушення. Ця підозра вперше чітко сформульована в офіційному документі - письмовому повідомленні про підозру. В ньому слідчий/прокурор викладає висновок про наявність і суть кримінального діяння, вчиненого конкретно особою. Прийняття рішення щодо повідомлення про підозру ще не означає, що мета розслідування досягнута і його можна завершити, оскільки потрібно допитати підозрюваного із приводу підозри, перевірити його показання, виконати інші слідчі (розшукові) і процесуальні дії, наслідком чого також може стати зміна, доповнення повідомлення про підозру [1, с. 162]. 
Необхідно зазначити, що повідомлення про підозру не підлягало оскарженню до 2018 р., адже в чинному КПК України була відсутня відповідна норма. Проте вимоги практичної діяльності стимулювали законодавчий орган унести зміни до кримінального процесуального законодавства. Так, у чинній редакції п. 10 ч. 1 ст. 303 КПК України зазначено, що на досудовому провадженні можуть бути оскаржені такі рішення, дії чи бездіяльність слідчого або прокурора: повідомлення слідчого, прокурора про підозру після спливу одного місяця із дня повідомлення особі про підозру у вчиненні кримінального проступку або двох місяців із дня повідомлення особі про підозру у вчиненні злочину, але не пізніше закриття прокурором кримінального провадження або звернення до суду із обвинувальним актом - підозрюваним, його захисником чи законним представником [4].

Загалом повідомлення про підозру можна умовно поділити на дві частини: інтелектуальна (складення та підписання) і фізична (вручення, роз'яснення прав), їх неможливо розділити. Тому, на думку практиків, не можна говорити про можливість оскарження повідомлення про підозру як прояву бездіяльності слідчого або прокурора.

Протилежною з цього питання є позиція О.І. Яновської, на думку якої повідомлення про підозру є певною процесуальною дією, яка складається з комплексу окремих дій: складання, підписання, вручення, роз'яснення прав підозрюваному. Повідомлення про підозру не можна назвати слідчою (розшуковою) дією чи звичайним документом.

Як зазначила О.І. Яновська, загалом оскарження повідомлення про підозру відповідно до п. 10 ст. 303 КПК України пов’язане не 3 порушенням процесуальних норм, а з обгрунтованістю підозри. Підозра сама собою є мінімальним стандартом у контексті доказування. На думку Європейського суду з прав людини, тут достатньо мінімальних ознак, які переконають стороннього спостерігача, що особа може бути причетна до вчинення кримінального правопорушення.

При цьому таке поняття як обгрунтованість підозри для місцевих судів здебільшого визначається думкою прокурора під час обрання підозрюваному запобіжного заходу. Варто звернути увагу, що така практика існує, незважаючи на наявність у законодавстві певних вимог до цього процесуального документу: необхідності зазначення, де й коли вчинено кримінальне правопорушення, склад кримінального правопорушення, номер Єдиного реєстру досудового розслідування, підпис слідчого і прокурора.

Вважаємо за необхідне розглянути практику оскарження повідомлення про підозру під кутом зору його обгрунтованості. Так, у січні 2016 р. один із суддів Рівненського міськрайонного суду постановив у своїй ухвалі, що не можна вважати повідомленням про підозру звичайний документ, складений під час обшуку слідчим і вручений брату підозрюваного. Тобто суд першої інстанції скасував повідомлення про підозру й визнав відсутність будь-яких підстав, передбачених статтею 42 КПК України для визнання особи підозрюваним [2].

Також на практиці відомі випадки, коли на підставі п. 1 ч. 1 ст. 303 КПК України адвокат оскаржував неналежно вручені повідомлення про підозру, хоча практика 3 даного питання залишається й надалі дискусійною. На думку адвоката, неправильно складене повідомлення про підозру або ж вручене неналежним чином є саме бездіяльністю слідчого або прокурора, водночас інколи слідчі судді в ухвалі зазначають, що це і не дія, і не бездіяльність, а тому оскарження повідомлення про підозру в порядку цієї статті не є можливим.

Варто зазначити, що доволі спірним $є$ п. 10 ч. 1 ст. 303 КПК України, згідно з яким новими змінами стороні захисту надано право на оскарження повідомлення слідчого/прокурора про підозру після спливу одного місяця із дня повідомлення особі про підозру у вчиненні кримінального проступку або двох місяців із дня повідомлення особі про підозру у вчиненні злочину, але не пізніше закриття прокурором кримінального провадження або звернення до суду з обвинувальним актом [4].

Здавалося б із першого погляду, що захисникам надається багато можливостей у доведенні необгрунтованості підозри, але ця норма є не зовсім дієвою, адже існує проблема «солідарності суддів», коли $є$ малоймовірним скасування повідомлення про підозру колегою-суддею [3].

У цьому разі захисникам варто оскаржувати такі дії, не обмежуючись процесуальним формулюванням вимог, та більш розгорнуто викладати правову позицію щодо кожної підстави визнання вчиненої дії або допущеної бездіяльності органом досудового розслідування незаконною. Необхідно зазначити, що саме так було скасовано повідомлення про підозру Апеляційним судом Миколаївської області.

В ухвалі суду №489/4210/18 від 14.09.2018 р. зазначалося, що вручення повідомлення про підозру повинне бути належним чином підтверджене особою, яка отримала повідомлення або ознайомлена з її змістом іншим шляхом. Сам факт його направлення поштою не $є$ доказом вручення. 
Так, слідчим було винесено повідомлення про підозру особі та в цей же день направлено повідомлення засобами поштового зв'язку рекомендованим повідомленням. Надалі слідчим було внесено відомості до ЄРДР у вказаному кримінальному провадженні щодо повідомлення про підозру. При цьому поштове відправлення з повідомлення про підозру фактично не було вручене та було повернуто слідчому з відміткою про неможливість вручення. Після отримання інформації про невручення особі повідомлення про підозру слідчим не було виключено з ЄРДР у вказаному кримінальному провадженні про дату та час повідомлення про підозру у вчиненні кримінальних правопорушень.

Оскільки поштове відправлення адресатом не отримано, відповідно повідомлення про підозру не допустимо вважати врученим. Принагідно зазначити, що, на думку О.Ю. Татарова, непоодинокими $є$ випадки «набуття статусу підозрюваного» з моменту направлення повідомлення про підозру поштою, оскільки відповідно до ст. 280-281 КПК України в розшук можна оголосити лише підозрюваного [5].

Оскарження бездіяльності слідчого щодо виключення відомостей з СРДР процесуальним законодавством не передбачено, проте є можливість включити такі вимоги у скаргу на повідомлення про підозру. Відповідно до п. 10 ч. 1 ст. 303 КПК України на досудовому провадженні може бути оскаржене повідомлення слідчого, прокурора про підозру [4].

В цій справі захисник звернувся до слідчого судді зі скаргою на повідомлення про підозру у кримінальному провадженні. Однією з вимог скарги було зобов'язати слідчого виключити відомості з ЄРДР про дату та час повідомлення про підозру. Слідчий суддя відмовив у задоволенні скарги, оскільки ст. 303 КПК України не передбачає оскарження такої бездіяльності. Таке рішення було оскаржене в апеляційному порядку на підставі прямої дії норм Конституції України. Апеляційний суд Миколаївської області задовольнив указану апеляційну скаргу в цій частині 3 огляду на наступне.

Відповідно до ст. 42 КПК України підозрюваним є зокрема особа, щодо якої складено повідомлення про підозру, однак не вручене ӥй унаслідок невстановлення місцезнаходження особи, проте вжито заходів для вручення у спосіб, передбачений КПК України для вручення повідомлень [4].

Згідно зі ст. 111 КПК України, повідомлення у кримінальному провадженні є процесуальною дією, за допомогою якої слідчий, прокурор, слідчий суддя чи суд повідомляє певного учасника кримінального провадження про дату, час та місце проведення відповідної процесуальної дії або про прийняте процесуальне рішення чи здійснену процесуальну дію, яке повинно мати певну форму і зміст.

Згідно $з$ ч. 2 ст. 135 КПК України, у разі тимчасової відсутності особи за місцем проживання повістка для передачі ій вручається під розписку дорослому члену сім'ї особи чи іншій особі, яка з нею проживає, житлово-експлуатаційній організації за місцем проживання особи або адміністрації за місцем їі роботи.

Так, Апеляційний суд Миколаївської області дійшов до висновку, що доводи захисника про те, що повідомлення про підозру, фактично не вручене його підзахисному, є слушними, оскільки слідчим не надано доказів виконання вимог ч. 2 ст. 135 КПК України [2].

Сам лише факт направлення поштою повідомлення про підозру не є доказом вручення його повідомлення. Оскільки, відповідно до положень ст. 136 КПК України, таке вручення повинне бути належним чином підтверджене особою, яка отримала повідомлення або ознайомлена з їі змістом іншим чином.

Хоча докази щодо фактичної необгрунтованості підозри судом не були прийняті до уваги, вважаємо, що суттєве порушення норм процесу з боку слідчого дозволило захисту позбавити особу статусу підозрюваного. Надалі стороною захисту були скасовані постанови про оголошення особи в розшук, про зупинення досудового розслідування та інші документи органу досудового розслідування [3].

Варто зазначити, що сформована судова практика з моменту внесення відповідних змін свідчить про небажання слідчих суддів проводити аналіз оголошеної підозри та перевіряти докази, якими вона обгрунтовується, посилаючись на те, що докази досліджуються судом при розгляді справи по суті. Тим самим слідчі судді фактично не реалізують функцію судового контролю за дотриманням прав, свобод та інтересів осіб у кримінальному провадженні.

Висновки. Отже, можна зробити висновок, що повідомлення про підозру може бути оскаржене як процесуальна дія, а підставою для ії оскарження, згідно з п. 1 ч. 1 ст. 303 КПК України, можуть слугувати порушення процесуальних норм. Варто зазначити, якщо досудове 
розслідування уже завершене, то повідомлення про підозру не оскаржити. Незважаючи на те, що в нормі це прямо вказано, але захисники все одно подають відповідні клопотання до слідчого судді. Якщо суд першої інстанції задовольнить скаргу про скасування підозри, не враховуючи терміни, вона, вірогідно, буде скасована в апеляційній інстанції.

\section{Список використаних джерел:}

1. Аленін Ю.П., Гловюк І.В. Повідомлення про підозру: загальна характеристика та проблеми удосконалення. Вісник Південного регіонального иеентру Національної академії правових наук Украӥни. 2014. № 1. С. 161-169.

2. Єдиний державний реєстр судових рішень. URL: http://www.reyestr.court.gov.ua/Page/1 (дата звернення: 21.02.2019).

3. Коломійчук В.О. Позбавлення статусу підозрюваного: лайфхак стороні захисту. Офіційний сайт Ліга.Блоги. URL: https://blog.liga.net /user/vkolomiychuk/article/31278 (дата звернення 12.05.2019).

4. Кримінальний процесуальний кодекс України : Закон України від 13.04.2012 № 4651-VI.

5. Татаров О.Ю. Проблеми повідомлення про підозру та шляхи їх вирішення». Науковий часопис Національної академї̈ прокуратури України. 2014. № 4. С. 179-186. 